\title{
The Nucleus Introduced
}

\author{
Thoru Pederson \\ Program in Cell and Developmental Dynamics, Department of Biochemistry and Molecular Pharmacology, \\ University of Massachusetts Medical School, Worcester, Massachusetts 01605 \\ Correspondence: thoru.pederson@umassmed.edu
}

Now is an opportune moment to address the confluence of cell biological form and function that is the nucleus. Its arrival is especially timely because the recognition that the nucleus is extremely dynamic has now been solidly established as a paradigm shift over the past two decades, and also because we now see on the horizon numerous ways in which organization itself, including gene location and possibly self-organizing bodies, underlies nuclear functions.

"We have entered the cell, the Mansion of our birth, and started the inventory of our acquired wealth."

-Albert Claude

Mhen I first read that morsel from Albert V Claude's 1974 Nobel Prize lecture it seemed Solomonic wisdom, as it indeed was. Though he was referring to cell biology en toto, the study of the nucleus was then at a tipping point and new advances were just at hand. Since then, the nucleus field has literally nucleated and we are now at a position to both admire the recent past and register excitement about the present and where the nucleus field may be headed.

\section{THE NUCLEUS DISCOVERED}

We cannot know who first saw the nucleus but we do know that the father of optical microscopy, Antony van Leeuwenhoeck, did so with amphibian and avian erythrocytes in 1710 and that in 1781 Felice Fontana did so as well in eel skin cells. More definitive accounts followed by Franz Bauer, who in 1802 sketched orchid cells and pointed out the nucleus (Bauer 1830-1838), as well as by Jan Purkyně, who described it as the vesicula germanitiva in chicken oocytes (Purkyně 1825), and Robert Brown who observed it in a variety of plant cells (Brown 1829-1832), earning additional fame for coining the term "nucleus" (for excellent accounts of these early descriptions of the nucleus see Gall 1996; Harris 1999). Of course, these early observations did not ascribe particular significance to this structure, the given name simply conveying its central location. Later, the nucleus was increasingly observed and became, with some prescience, a key tenet of the cell theory. The nucleus remained a rather lonely item in the eukaryotic cell's parts list for many

Editors: David L. Spector and Tom Misteli

Additional Perspectives on The Nucleus available at www.cshperspectives.org

Copyright (C) 2011 Cold Spring Harbor Laboratory Press; all rights reserved; doi: 10.1101/cshperspect.a000521

Cite this article as Cold Spring Harb Perspect Biol 2011;3:a000521 
decades, until the discoveries of discrete cytoplasmic entities, e.g., mitochondria, the Golgi apparatus etc. (reviewed in Wilson 1925).

\section{THE NUCLEUS INHERITED}

We do not know how and when the genome of an ancestral cell first became encased in a primitive nucleus. We have no evidence that cells living in the RNA world ever had a membrane (or any other structure) around the genome, i.e., that they ever became nucleate. Once a ribozyme RNA replicase arose, anything would have been possible including the emergence of ribozymes with lipid biosynthetic activities.

Enthalpy-favored or free energy-driven events could then have led to stabilizing selection of RNA-lipid affinities and on from there. A cottage industry of experiments on the interactions of lipids with RNA has emerged in the chemical biology field in the past decade but the significance of these studies to prebiotic systems and the earliest cells remains speculative. As for the advent of the DNA world, and of eukaryotes, a major concept is that a prokaryote organism was invaded by another, nonnucleated cell, setting up an endosymbiotic relationship, with the entering organism's outer membrane seeding what would become the nuclear envelope. The major proponent of this plausible idea has also suggested that this hypothetical invader also brought in a centriole, the forerunner of what we know as the centriole/ basal body in extant eukaryotes (Margulis et al. 2000). We can not play the videotape of life on Earth backwards and although we can reconstruct some things with a degree of empirical confidence, albeit amidst debate (reviewed by Misteli 2001a; Poole and Penny 2001; Rotte and Martin 2001), or speculation (e.g., Lake 2009), when it comes to how the nucleus arrived, we just do not know.

\section{THE NUCLEUS ENVELOPED}

Notwithstanding the uncertainty of its evolutionary origin, the nucleus is bounded by a double membrane, the nuclear envelope, which in many cells is contiguous with the endoplasmic reticulum. The frequently observed intimacy of the nuclear envelope with the endoplasmic reticulum has been often under-appreciated, particularly as it bears on the isolation of nuclei and issues of resulting purity. There is also growing interest in how nuclear membrane proteins may be integrators of nuclear and cytoplasmic organization and dynamics (e.g., King et al. 2008; Roux et al. 2009; Starr 2009).

A seminal finding was that the nuclear envelope contains pores (reviewed by Gall 1964; 1967), which have now been defined in considerable compositional and structural detail (e.g., Alber et al. 2007; Fernandez-Martinez and Rout 2009). A somewhat less familiar but equally important area of investigation has revealed that the nuclear envelope harbors a signal transduction system of its own, featuring players in common with the plasma membrane, for example the lipid-linked inositol trisphosphate system (Martelli et al. 1991; for reviews see Divecha et al. 1993; Cocco et al. 2009; Barton et al. 2010).

\section{THE NUCLEUS DIVERSIFIED}

However the nucleus arose, it went on to display a variety of organizations. These range from the highly condensed nuclei of mature erythrocytes in nonmammalian vertebrates to the bimorphic nuclei in almost all ciliates. In the latter organisms a micronucleus perpetuates the genome whereas a macronucleus contains DNA fragments that represent only a fraction of the organism's genome complexity and which encode the RNAs and proteins needed for vegetative life. It was a particular feature of this genomic strategy, namely the macronuclear amplification of the ribosomal RNA genes (Gall 1974), that led to the discovery of the telomere DNA sequence (Blackburn and Gall 1978). It was also in these ciliates that selfsplicing RNA was discovered and in which the era of chromatin epigenetic marks was launched (reviewed in Pederson 2010).

\section{THE NUCLEUS VIEWED}

Beyond early observations made by bright field microscopy, the staining method developed by 
The Nucleus, Introduced

Robert Feulgen, which attaches a dye to aciddepurinated DNA, was a major tool in advancing the DNA = gene theory, based on studies of the DNA content of haploid versus diploid cells by a graduate student, Hewson Swift, in the laboratory of Arthur Pollister at Columbia University, and concurrent ones by Hans Ris in the laboratory of Alfred Mirsky at the Rockefeller Institute (reviewed by Pederson 2005). Although biochemical measurements of the DNA contents of germ versus somatic cells had revealed a twofold difference, these findings mostly remained in the biochemical community and did not have as much impact as might have been expected. It was the Feulgen cytophotometry results that helped catalyze the idea that DNA is genes. This was, to borrow part of Winston Churchill's famous phrase-"the end of the beginning" (Avery et al. 1944).

Meanwhile, phase contrast microscopy had beautifully revealed the interphase nucleus and mitotic chromosomes, the latter not "nuclear" in the strictest sense. Electron microscopy led to the visualization of the double nuclear membrane and nuclear pores (Gall 1964; 1967), the tripartite structure of the nucleolus (Bernhard et al. 1952), the nuclear lamina (Fawcett 1966), and subsequently the observation of chromatin $v$-bodies (Olins and Olins 1974), later re-named nucleosomes (Oudet et al. 1975).

An intriguing nuclear structure first observed by the Spanish neuroanatomist Santiago Ramon y Cajal (Cajal 1903, 1910) underwent a renaissance of interest when one of its protein components was identified by Eng Tan and colleagues (Andrade et al. 1991; Raska et al. 1991). Initially termed the coiled body, a campaign in 1999 by Joseph Gall resulted in a consensus to rename this structure the Cajal body. Gall has made some of the most seminal advances in our understanding of this nuclear body (for reviews see Gall 2000; Handwerger et al. 2006; Gall 2009; Nizami et al. 2010). Similarly, in the 1990s the nucleolus, interchromatin granule clusters (a.k.a. nuclear speckles) and other nuclear bodies also underwent advances in molecular definition (reviewed by Spector 1993; Pederson 2002a; Spector 2001; 2006).

\section{THE NUCLEUS ISOLATED}

Using pus-soaked bandages from a local hospital, Friedrich Miescher discovered DNA in the late 1860s. As described in a richly detailed historical account (Portugal and Cohen 1977), Miescher wrote a manuscript and submitted it to a top journal but had to sit by and wait while the editor (and his former mentor), Felix Hoppe-Seyler, checked the findings in his own lab, resulting in the publication of two concurrent papers (Miescher 1871; Hoppe-Seyler 1871). Over the next 90 years, efforts to isolate nuclei did not go very far. In the 1960s Alfred Dounce at the University of Rochester, Van Potter and Conrad Elvehjem at the University of Wisconsin, and Philip Siekevitz and George Palade at the Rockefeller Institute pioneered the isolation of nuclei from animal tissue. (The Rochester and Wisconsin investigators had the homogenizers they developed named for them.) Important advances in isolating nuclei from plant tissue were made at approximately the same time by James Bonner's group at Caltech. Later, groups at Baylor College of Medicine (Harris Busch), Rockefeller University (Alfred Mirsky) and Albert Einstein College of Medicine (Sheldon Penman) published refined methods. As is the case for most cell fractionation methods, none of these proved to be perfect but they were major advances nonetheless.

The fact that the endoplasmic reticulum and the nuclear envelope are contiguous in many cells is but one example of this challenge, and the tendency of the cytoplasmic intermediate filament system to often collapse upon the nucleus during cell fractionation is yet another. The pioneer methods of nuclear isolation employed sucrose concentrations in which the tissue homogenate was exposed to hydrodynamic forces and/or sucrose density differences that caused cytoplasmic elements and adherent endoplasmic reticulum to separate from the nuclei. The most popular of the early methods (Chauveau et al. 1956) was subsequently refined in important ways to further minimize cytoplasmic contamination (Maggio et al. 1963; Blobel and Potter 1966), with these two latter advances constituting the gold standard of 


\section{T. Pederson}

nuclear isolation for many years, and still today for many tissues.

As regards methods aimed at single-cell studies, an important method (Penman 1966) involved swelling cells in a hypotonic buffer so that the expanded cell volume would collide with the hydrostatic shear forces delivered by a 0.0015-inch clearance stainless steel device, patterned after ones introduced by Dounce. Detergent-based methods were also introduced (Traub et al. 1964). These typically employed Triton X-100 or Royal Dutch Shell's "nonionic P-40" (a.k.a. NP-40). These breach the plasma membrane and, depending on cell type, also strip away the endoplasmic reticulum. In some cases, NP-40 collapses some of the plasma membrane onto the nucleus, so that nuclei prepared by this method may not always be as pure as some investigators have assumed. For some cells, the main advantage of the NP-40 method is less the nuclear fraction, but the relatively high purity of the ribosomes that are released (Borun et al. 1967).

All methods of nuclear isolation must be monitored both for what remains attached from the cytoplasm (or is taken up from it), as well as what is lost from within. Various markers have been used to assess the depletion of cytoplasmic material in isolated nuclei, based on the presumption that the true intracellular locations of such markers are known to some degree of certainty. In one study, HeLa cell nuclei were isolated in a buffer consisting of a previous cytoplasmic fraction from ${ }^{3} \mathrm{H}$-leucine-labeled cells (Bhorjee and Pederson 1972), thus allowing the level of cytoplasmic protein contamination of the nuclei to be readily estimated.

Issues of nuclear purity loomed large in early studies claiming that protein synthesis occurs in the isolated nuclei (and thus presumably within nuclei in vivo) but this work was challenged on several grounds (reviewed by Goldstein 1970; Pederson 1976). More recently this issue has resurfaced (e.g., Iborra et al. 2001, although this study also included intact cell experiments). Various controls for nuclear purity have been better but still not sufficient to quiet all doubts as to the source of apparent protein synthesis in isolated nuclei (for reviews see Pederson 2001a; Dahlberg et al. 2003; Nathanson et al. 2003). Meanwhile, less attention has been devoted to analyzing not what is adsorbed to nuclei as opposed to what is lost from nuclei during various isolation methods.

There have been other instructive guideposts over the years for judging the purity of nuclear fractions. An instructive vignette is the saga of the biosynthesis of the U-rich spliceosomal small nuclear RNAs. We now know that they are exported to the cytoplasm as $3^{\prime}$ extended precursors, there to be trimmed, $5^{\prime}$-cap hypermethylated and assembled with various proteins before re-entry into the nucleus as functional snRNPs. Although many studies had pointed to this pathway at varying degrees of cogency, it was the use of two particular nuclear isolation methods, each with exceptionally strong credentials, that led to acceptance of this pathway of snRNP biogenesis (Gurney and Eliceiri 1980; Zieve et al. 1988). This was further solidified by the demonstration that exogenous U2 snRNA precursor molecules introduced into the cytoplasm of mammalian cells enter this pathway and become $3^{\prime}$ trimmed, cap hypermethylated, and assembled into snRNPs, followed by nuclear uptake (Kleinschmidt and Pederson 1990).

Another example of how the critical issue of nuclear purity was addressed arose in a study in which the total sequence complexity of nuclear versus cytoplasmic RNA was measured (Holland et al. 1980). Because the nuclear RNA was anticipated to have a higher sequence complexity than cytoplasmic RNA, contamination of the cytoplasmic fraction by leaked nuclear RNA loomed large. Accordingly, an experiment was undertaken in which the cells were labeled with an RNA tracer for a very short time (2 min), far too brief for any labeled transcripts to be exported to the cytoplasm in vivo, before cell fractionation. The label was followed throughout the isolation of the cytoplasmic fraction and polyribosome-associated mRNA, which revealed that no more than $0.03 \%$ of the nuclear RNA synthesized in the previous 2 min was present in the final mRNA preparation (Holland et al. 1980). Given that these 
kinds of controls are conceptually obvious and experimentally quite facile, it is surprising how rarely they have been employed in studies in which knowing the purity of a nuclear or cytoplasmic fraction is essential to weighing the findings.

Beyond the isolation of nuclei in bulk, there is the gold standard of manual isolation of nuclei from material that affords this opportunity (e.g., Duryee 1954; later refined and reviewed by Lund and Paine 1990; Paine et al. 1992). In a recent application of this approach, frog oocyte nuclei were manually isolated under oil and the relative densities of the nucleolus versus surrounding nucleoplasmic bodies were determined by differential interference light microscopy, with results that defied most expectations (Handwerger et al. 2005). For most of the cells and tissues from which one wants to isolate nuclei, manual isolation is of course out of the question. But it is worth emphasizing that what has been learned from occasional studies employing manually isolated nuclei is likely to be a more reliable guide to understanding nuclear organization and function than has sometimes been realized by those members of the nucleus research community whose work is based on bulk nuclear isolation.

A general point to be made is that although isolated nuclei served many important experimental uses during the modern era of research on the nucleus, their role in advancing the biochemistry of gene expression was surprisingly short-lived and quite limited. Cell-free systems based on isolated nuclei played only transitory and rather minor roles in the areas of DNA replication, transcription, and mRNA processing-usually giving way to more efficient soluble systems in short order. An exception was the use of isolated nuclei to allow RNA polymerase II to continue transcription and thus, by hybridization analysis of the extended chains, determine the boundaries of a transcription unit (Weber et al. 1977). In contrast to these limited roles of isolated nuclei in the investigation of gene expression, a very different cell-free system derived from frog eggs (Newport and Forbes 1987) was of monumental importance in advancing our understanding of chromatin and nuclear envelope assembly and the control of cell-cycle progression.

\section{THE NUCLEUS COMPOSED}

In 1976, the Federation of American Societies of Experimental Biology (FASEB) heroically collated all available information on the "properties of cells" and I was chosen to organize and edit the chapter on the nucleus. At the suggestion of the editors, and with FASEB's permission, we are republishing here the tables of data on the nucleus from the original volume (Altman and Katz 1976) (see supplemental data online). These tables speak to painstaking analytical work carried out in a time gone by and rarely pursued today. But let there be no mistake, the concentrations of protein or RNA in various preparations of isolated nuclei, or extracts derived from them, can be a critical factor in the interpretation of certain kinds of studies. What is needed now to complement these important compositional data is additional biophysical information (reviewed in Pederson 2002a). One important step in this direction is that the fluid viscosity of the interchromatin space has now been estimated, based on diffusion coefficients of reporter molecules, to be approximately one-fifth that in water (Wachsmuth et al. 2000). The considerations of fluid viscosity and free versus anomalous diffusion are critical to the understanding of intranuclear transport and nuclear body dynamics (Wachsmuth et al. 2000). In terms of chemical kinetics one would also want to know the water concentration in the nucleus. Only then could one know, or at least estimate, the ionic strength of the solvent phase and the true concentrations of solutes. The importance of these biophysical parameters is conveyed by the fact that only a relatively small change in the intracellular ion concentration elicits a dramatic mitosis-like state, which is completely reversible (Robbins et al. 1970). Polyamines are abundant constituents of the nucleus in most cells and yet their possible functions are rarely considered. Iron is a surprisingly abundant component of the interphase nucleus and mitotic chromosomes and is essential for DNA 
replication (Robbins and Pederson, 1970). Many compositional issues such as these are rarely considered in current research on the nucleus and yet they can be extremely determinative. But, happily, there are steps in this direction, as biophysicists increasingly join the nucleus research community (for an "interdisciplinary" review see O’Brien et al. 2003).

\section{THE NUCLEUS DECONSTRUCTED}

Major advances in biology were made by teasing a cell or its parts out, as from the squid giant axon, leading to the discovery of kinesin, or by glycerinating rabbit muscle to discover the biochemistry of its contraction. The major conceptual discovery about the nucleus, that it contains the genome, did not involve its dissection. But a desire to know its parts naturally arose in due course. Early attempts to isolate chromatin were made by the laboratories of Alfred Mirsky (Rockefeller) and James Bonner (Caltech) but these fractions were of dubious enrichment and the major advances in the field of chromatin and chromosome structure came from in situ studies (reviewed by DuPraw 1970). One of the first, convincing isolations of a subnuclear component was that of the nucleolus from starfish oocytes (Vincent 1955). Later, three groups went further. Palade and Siekevitz at Rockefeller purified guinea pig liver nuclei, subjected them to sonication and isolated nucleolar and nucleoplasmic fractions (Maggio et al. 1963). The demonstrated degree of fractionation was impressive and this work constituted one of the most important advances in the nucleus field at the time. Meanwhile, the laboratory of Harris Busch at Baylor College of Medicine developed a similar, sonication-based method for isolating nucleoli from rat hepatoma cells (Muramatsu et al. 1963) and subsequently this group, notably Ramachandra Reddy, exploited this method to identify a number of small nucleolar and nucleoplasmic RNAs long before their functions became known (for a review see Reddy and Busch 1988). Shortly thereafter, Sheldon Penman developed a method to resolve a HeLa cell nuclear fraction into nucleoli and nucleoplasm (Penman 1966).
His method involved the use of DNAse and high ionic strength and produced nucleolar and nucleoplasmic fractions that were less native than those obtained by the sonication method, although it led to spectacular advances in our understanding of RNA biosynthesis.

More recently, mammalian and plant cell nucleoli have been purified and subjected to extensive proteomic analyses (Andersen et al. 2002; Scherl et al. 2002; Pendle et al. 2005; Hinsby et al. 2006; for reviews see Dundr and Misteli 2002; Pederson 2002b; Couté et al. 2006 ; Leung et al. 2006). Nucleoplasmic bodies known as interchromatin granule clusters (a.k.a. "speckles") were isolated by David Spector and colleagues (Mintz et al. 1999) and later subjected by this group to proteomics analysis (Saitoh et al. 2004; reviewed in Lamond and Spector 2003). Meanwhile, Cajal bodies (reviewed by Gall 2000, 2009; Nizami et al. 2010) were isolated by Angus Lamond's laboratory (Lam et al. 2002). An exciting aspect of this recent period was that these nuclear bodies were being analyzed in such molecular detail at the very time the dynamics of their components were being observed in live cell studies, as will be discussed below.

Another nuclear structure appears in some cells, the perinucleolar compartment (Huang et al. 1997; 1998), and its presence has recently been found to have promising prognostic value in the staging of breast carcinoma (Kamath et al. 2005). It is a discoid, caplike structure intimately attached to the nucleolus and has thus resisted isolation so far. There presently are no clues to its function, beyond its accretion of certain small RNAs transcribed by RNA polymerase III (Matera et al. 1995; Weng et al. 2003).

\section{THE NUCLEUS TERRITORIALIZED}

A major development was the discovery that interphase chromosomes occupy specific locations (Zorn et al. 1979; Cremer et al. 1982), which to some extent had been anticipated from classical studies of the arrangement of chromosomes in the metaphase plate (Rabl 1885 ) and by the actual coining of the term "chromosome territory" (Boveri 1909). The 
modern concept of chromosome territories was promptly adopted in certain sectors of the human genetics and radiation biology communities but took more than two decades to gain broader traction (reviewed by Cremer and Cremer 2001; 2006), now with appreciated relevance to chromosomal translocations (see Pederson 2003 for a review), genome evolution (Tanabe et al. 2002; Foster and Bridger 2005) and the entire issue of how chromosome location relates to gene density and/or expression. This latter area has been hyperactive in the past few years (reviewed by Spector 2003; Pederson 2004; Gilbert et al. 2005; Sprout et al. 2005; Cremer et al. 2006; Akhtar and Gasser 2007; Misteli et al. 2007; Sexton et al. 2007; Takizawa et al. 2008; Towbin et al. 2009; Deniaud and Bickmore 2009) but the results have been surprisingly variable and confounding (for a particularly lucid summary see the Introduction in Meaburn et al. 2008). A distinct possibility that has arisen recently is that gene positioning is self-organizing, based not on expression per se but on the potential for sets of genes to be coregulated (Rajapakse et al. 2009; reviewed by Misteli 2009).

A clinical feature of chromosome territoriality is the fact that the extreme cytological manifestation of gene repression, i.e., heterochromatin, has long served as a key landmark for pathologists, both in its extent and location. But an exciting new dimension of diagnostic potential lies in studies, mentioned earlier, of intranuclear gene locations in relation to not only reciprocal translocations (Roix et al. 2003; reviewed in Pederson 2003) but in more recent work on gene repositioning in solid tumors (e.g., Meaburn et al. 2009).

The nucleus is territorialized not only with respect to the locations of the chromosomes themselves but also to a considerable extent with respect to the layout of expressed versus silenced genomic regions. This aspect of the nuclear structure field has recently taken one particularly surprising turn, reminding us that we are still in the early days. In most cells, heterochromatin is located at the nuclear periphery or in close approximation to the nucleolus. Remarkably, it has recently been reported that in the rod photoreceptor cell nuclei of nocturnal animals, the heterochromatin is coalesced into a large central domain in the nucleus with the euchromatin displaced to more peripheral locations, with plausible speculations as to the efficiency of light transmission and retinal harvesting (Solovei et al. 2009; reviewed by Ragoczy and Groudine 2009).

Another important recent development has been the introduction of methods to capture the interchromosome regions that lie in closest juxtaposition (Dekker et al. 2002; reviewed by Dostie and Dekker 2007). With this new methodology the field of genome organization is moving to a $4-\mathrm{D}$ spatialtemporal registration, which is itself likely to be determinative of phenotype. The extraordinary packing density of interphase chromatin has been recently investigated with "Hi-C", a powerful variation of the chromosome conformation capture methodology (LiebermanAiden et al. 2009; for a review see Langowski 2010).

\section{THE NUCLEUS NOT LIKELY MATRIXED}

Breaking up nuclei with sonication is one thing, extracting them with salt is another. The latter was a major effort of many labs in the 1950s and thereafter, most notably for isolating and characterizing histones. But others (e.g., Zbarsky and Georgiev 1959) employed graded salt extractions to fractionate total nuclear components. This yielded successive fractions of differing composition, not unexpected because the zwitterion concept of protein net charge had long been discovered by Arne Tiselius and advanced by John Edsall. There was therefore no reason to believe that cell components such as nuclei, mitochondria, or ribosomes would not release different sets of proteins as the ionic strength is elevated. Few cell biologists were comfortable with assigning a residue of the nucleus any relationship to the in vivo situation.

But in 1974 this nuclear residue got renamed a "nuclear matrix" (Berezney and Coffey 1974) and later work gave rise to the idea that chromatin and nascent RNA are attached to it. 


\section{T. Pederson}

The notion took hold in some quarters and gained a degree of traction as all sorts of entities were observed to be present in this fraction. But there was never any proof of the in vivo existence of such a structure nor is there proof today (for detailed reviews see Pederson 1998; 2000) and many leaders in the field of nuclear structure and function question the nuclear matrix concept. The consensual skepticism as to a nucleuswide, arborized network of filaments extending throughout the nucleoplasm certainly does not rule out the existence of short-range structural motifs.

\section{THE NUCLEUS IN DIVISION}

The current focus of the cell division field on chromosome capture by kinetochoremicrotubule interactions, how anaphase works mechanistically and the operation of mitotic checkpoints is of course well justified. But it is also possible that this emphasis may be missing one of the most intriguing of all events - the formation of daughter nuclei. Precursors of the nucleolus, nuclear envelope, and nuclear lamina congress, mature, and assemble in "daughter to be" cells as early as anaphase and definitively in telophase. This presently subsidiary effort in the cell division field needs more momentum as it is no less intriguing than anaphase, and likely involves very different mechanisms such as the free energy of DNA-lipid affinities and other chemical phenomena that are unique to telophase and the assembly of daughter nuclei, seemingly via pathways whose memory had not been erased from the previous mitosis.

\section{THE NUCLEUS IMAGED}

In his detailed recipes, the histochemistry pioneer A.G. Everson Pearse described various ways to stain cells, including the nucleus (Pearse 1961). I tried many of these methods as a student including the aforementioned Feulgen reaction. The combination of methyl green and pyronin ended up as my favorite, with which I first saw nucleoli, to become a longstanding interest. At the end of the classical era, immunostaining and susbsequently the advent of GFP advanced the localization of nuclear proteins and bodies, and the discovery of in situ nucleic acid hybridization (Gall and Pardue 1969) made possible the localization of both genes and RNAs. These methods, especially when powerfully used in combination, have made it possible to even demarcate subregions of nuclear domains formerly thought to be relatively homogenous, such as the granular component of the nucleolus, which now appears to be a landscape of distinct molecular zones rather than a uniform lawn of nascent ribosomes (Politz et al. 2002; 2005). Of course, these light microscopy advances have left ample room for the continuing application of electron microscopy. Particular progress has been made in the past two decades with respect to the ultrastructural analysis of both nuclear pore complexes, as mentioned earlier, as well as a defined messenger RNP, sometimes the two caught together (Mehlin et al. 1992).

\section{THE NUCLEUS IN MOTION, WITHIN}

There was never much doubt that, around the less mobile chromosomes and nucleoli, molecules roam the nucleus. This emerged from numerous studies in which tagged molecules were microinjected into the nucleus and observed to display high mobility (e.g., Wang et al. 1990). Subsequently it became possible to express fluorescently tagged nuclear proteins and observe their dynamics. The first such study examined the dynamics of interchromatin granule clusters (Misteli et al. 1997) which revealed these nucleoplasmic bodies to be more dynamic than had been anticipated. Then, a new wave of studies appeared resulting from the application of the method of fluorescence recovery after photobleaching (FRAP). In the first of these, FRAP was employed to study the mobility of the DNA repair machinery tagged with GFP (Houtsmuller et al. 1999). This paper represented both a technical and conceptual milestone and soon thereafter FRAP was applied to several other nuclear proteins in a boomlet of important studies (Kruhlak et al. 2000; Lever et al. 2000; Misteli et al. 2000; Phair and Misteli 2000; Boisvert et al. 2001; Chen and 
Huang 2001; reviewed in Pederson 2000b; Misteli 2001b; Pederson 2001b; Phair and Misteli 2001). These revealed much more rapid and/ or more extensive dynamics than would have been anticipated from either earlier in vitro work, or from the apparent stasis of certain nuclear bodies, constituting a true paradigm shift in the nucleus field (reviewed by Misteli 2001b). Even the nuclear lamina, which had long been viewed as one of the most stable structures in the nucleus, was found to undergo dynamic exchange of subunits, leading to an appreciable nucleoplasmic concentration (Moir et al. 2000; reviewed by Dechat et al. 2008) and there is increasing evidence that the dynamic lamins have functions while in the nucleoplasm (Malhas et al. 2007; Lee et al. 2009; reviewed by Shimi et al. 2008; Shumaker et al. 2008), and it now appears that nucleoporins do as well (Capelson et al. 2010; Kalverda et al. 2010).

This wave of FRAP studies addressed the dynamics of protein constituents of nuclear bodies and was, of course, based on GFP. But GFP also enabled investigation of the movements of nuclear bodies and their constituents. Studies of the movements of chromosomes (Marshall et al. 1997; reviewed by Gasser 2002), promyelocytic leukemia (PML) bodies (Muratani et al. 2002) and Cajal bodies (Platani et al. 2002) were the first of these. The Marshall et al. study was ahead of its time and it was amusing to recall the incredulity expressed by some that interphase chromosomes, relatively giant structures, are moving, and with no dependence on metabolic energy. But others properly anticipated that there is of course no reason the chromosomes would not display this microscopic biophysical property, viz. the manifestation of the kinetic energy of any particle.

Although GFP enabled these studies (for reviews see Misteli et al. 1997; Eils et al. 2000; Pederson 2000b; Misteli 2001b; Pederson 2001b; Chubb and Bickmore 2003; Dundr et al. 2002; Gasser 2002), investigating the intranuclear movements of the other major nuclear species, RNA, required different innovation. The fact that microinjection of a pre-mRNAs or small nucleolar RNAs into the nucleus of mammalian cells resulted in localization with sites known to contain splicing machinery or the nucleoli, respectively (Wang et al. 1990; Jacobson et al. 1995; Jacobson and Pederson 1998; reviewed in Pederson 2001c) showed that introduced RNA is mobile. Further innovations led to tagging of endogenous RNA and these studies confirmed that poly(A) RNA is highly diffusive in the nucleus (Politz et al. 1998; 1999; reviewed in Politz and Pederson 2000; Pederson 2001c), and subsequent studies revealed, importantly, that this was true of specific mRNAs (Singh et al. 1999; Shav-Tal et al. 2004) and also 28S ribosomal RNA (Politz et al. 2003). These approaches also made it possible to investigate the live cell dynamics of RNA in relation to specific intranuclear structures, e.g., interchromatin granules (Politz et al. 2006). An increasing number of single-molecule level studies of nuclear molecular dynamics have appeared recently (Dange et al. 2008; Grünwald et al. 2008; Siebrasse et al. 2009) and, together with revolutionary advances in the spatial resolution of diffraction-limited optical microscopy (for a brief review see Pederson 2006), one senses the dawning of a new era as systems biology enters the nucleus, or vice-versa (reviewed by Gorski and Misteli 2005). Another major advance was the introduction of a method to tag specific chromatin regions via the binding of GFP-tagged lac repressor to an integrated tandem array of the lac operator (Robinett et al. 1996), which in turn allowed the visualization in living cells of gene activation at discrete loci (Tsukamoto et al. 2000; Janicki et al. 2004) and the dynamics of transcription factors (Becker et al. 2002; Karpova et al. 2008; Sprouse et al. 2008). As mentioned earlier, the movements of interphase chromosomes have implications for the statistics of reciprocal exchanges between interphase chromosomes, with disease relevance (Roix et al. 2003; reviewed by Pederson 2003). Nucleoli also move to the extent that the chromosomes which contain the repeated rRNA genes are mobile. Diffusion, by definition, arises from the thermal energy inherent in the particle itself. However, the possibility that gene repositioning may be mediated by a process 
that uses metabolic energy has recently been the topic of initial studies (and debate). There is a growing body of evidence for actin and myosin in the nucleus, a field that has moved past its initial uncertainties and is now addressing functions (reviewed by Pederson and Aebi 2002; 2005; Pederson 2008). In particular, three recent studies have implicated actin-based processes in gene repositioning (Chuang et al. 2006; Dundr et al. 2007; Hu et al. 2008). This emerging concept is among the most deserving of vigilance in the nucleus field at this time.

\section{THE NUCLEUS THAT AWAITS US}

Speculation is always risky. One thing is clearthe question of how nuclear bodies arise in the first place (reviewed by Misteli 2001c) has taken on a new dimension because of the discovery that a Cajal body can assemble when key components are experimentally addressed to a specific nuclear site (Kaiser et al. 2008). Other recent studies raise the possibility that noncoding, nucleus-retained RNAs may play roles in nuclear architecture (Clemson et al. 2009; Sasaki et al. 2009; Sunwoo et al. 2009; reviewed by Wilusz et al. 2009). Also on the present horizon are stem cell issues that call for increasing input from experts on the nucleus. Stem cells have been hyped but it is early days and the nucleus cell biology community has much to offer, both by science and skepticism (for the latter perspective see Lander 2009). The essence of "stem-cellness" is an asymmetric descent of phenotypic potential vs. maintaining a continual seed of replenishment. So the two daughter cells have to be profoundly different but it is a difference we presently grasp very dimly. This is as deep a problem in cell biology as there is today, and there are already encouraging signs of progress (e.g., Parnell and Stillman 2008). Another field that is ripe for the intervention of nucleus experts is somatic nuclear transfer, in which it is the reaction of the introduced nucleus to the maternal environment, known to be dominant from classical studies, that sets in motion the reprogrammed developmental events. What are the molecules that underlie this powerful influence of the egg cytoplasm?
Finally, there can be no doubt that the increasing ability to study nuclear dynamics and function in living cells, now reaching single molecule level detection, constitutes one of the most powerful advances. The recent breaking of the classical diffraction limit of optical microscopy brings the nucleus into nanoscale range. The possible coaptation of these breakthrough approaches with instructive cell types and model systems stirs excitement for what lies ahead. The nucleus research community is living in very interesting times.

\section{CODA}

The assumption underlying this collection on nuclear structure and function is that the nucleus has reached a stage of enabling coherence as part of the epistemological structure of modern biological science. However, there are likely to be many things about the nucleus that we don't yet know and may not know anytime soon. We can only hope that what the geneticist J.B.S. Haldane posited on the cosmos will prove not to be true for the nucleus: "Now, my suspicion is that the universe is not only queerer than we suppose, but queerer than we can suppose." If we appropriately bear in mind that the nucleus may be more complicated than we may have once thought, and yet just may be knowable, then this very belief may empower us and our students and successors to penetrate the subject's awaiting depths, the next of which now beckon. There is every reason to believe in this program. So let us be of good cheer.

\section{ACKNOWLEDGMENTS}

I am indebted to Joseph Gall for characteristically insightful suggestions on the manuscript. Cited work from the author's laboratory was funded by grants from the National Institutes of Health (GM-21595, GM-23914 and GM-60551), the National Science Foundation (MCB-0445841), the American Cancer Society (CD-126), and the G. Harold and Leila Y. Mathers Foundation. Some important ideas 
that stirred in the modern era of the nucleus field were catalyzed by a series of symposia convened by the author at the Marine Biological Laboratory, Woods Hole, supported by a grant from the Grass Foundation and the late Ellen Grass.

\section{REFERENCES}

Akhtar A, Gasser SM. 2007. The nuclear envelope and transcriptional control. Nat Rev Genet 8: 507-517.

Alber F, Dokudovskaya S, Veenhoff LM, Zhang W, Kipper J, Devos D, Suprato A, Karni-Schmidt O, Williams R, Chait BT, et al. 2007. The molecular architecture of the nuclear pore complex. Nature 450: 695-701.

Altman PL, Katz DD. 1976. Biological Handbooks. I. Cell Biology. Federation of American Societies for Experimental Biology, Bethesda, Maryland.

Andersen JS, Lyon CE, Fox AH, Leung AKL, Lam YW, Steen H, Mann M, Lamond AI. 2002. Directed proteomic analysis of the human nucleolus. Curr Biol 12: 1-11.

Andrade LEC, Chan EKL, Raška I, Peebles CL, Roos G, Tan EM. 1991. Human autoantibody to a novel protein of the nuclear coiled body: immunological characterization and cDNA cloning of p80-coilin. J Exp Med 173: 14071419.

Avery OT, MacLeod CM, McCarty M. 1944. Studies on the chemical nature of the substance inducing transformation of pneumococcal types. I. Induction of transformation by a deoxyribonucleic acid fraction isolated from pneumococcus type III. J Exp Med 79: 137-158.

Barton CA, Laishram RS, Anderson RA. 2010. Nuclear phosphoinositides: a signaling enigma wrapped in a compartmental conundrum. Trends Cell Biol 20: 25-35.

Bauer F. 1830-1838. Illustrations of orchidaceous plants Ridegway, London.

Becker M, Baumann C, John S, Walker DA, Vigneron M, McNally JG, Hager GL. 2002. Dynamic behavior of transcription factors on a natural promoter in living cells. EMBO reports 3: 1188-1194.

Berezney R, Coffey DS. 1974. Identification of a nuclear protein matrix. Biochem Biophys Res Commun 60: 14101417.

Bernhard W, Haguenau F, Oberling C. 1952. L'ultrastructure du nucleole de quelques cellules animals, révélée par le microscope électronique. Experientia 8: 58-63.

Bhorjee JS, Pederson T. 1972. Nonhistone chromosomal proteins in synchronized HeLa cells. Proc Natl Acad Sci 69: $3345-3349$.

Blobel G, Potter VR. 1966. Nuclei from rat liver: isolation method that combines purity with high yield. Science 154: $1662-1665$.

Blackburn EH, Gall JG. 1978. A tandemly repeated sequence at the termini of the extrachromosomal ribosomal RNA genes in Tetrahymena. J Mol Biol 120: 33-53.

Boisvert FM, Kruhlak MJ, Box AK, Hendzel MJ, BazettJones DP. 2001. The transcription coactivator CBP is a dynamic component of the promyelocytic leukemia nuclear body. J Cell Biol 152: 1089-1106.
Borun TW, Scharff MD, Robbins E. 1967. Preparation of mammalian polyribosomes with the detergent Nonidet-P40. Biochim Biophys Acta 149: 302-304.

Boveri T. 1909. Die blastomerenkern von Ascaris megalocephala und die theorie der chromosomenindividualität. Arch Zellforsch 3: 181-268.

Brown R. 1829-1832. Observations on the organs and mode of fecundation in Orchideae and Asclepiadeae. Trans Linn Soc Lond 16: 685-746.

Cajal SRy. 1903. Un sencillo metodo de coloracion selectiva del reticulo protoplasmatico y sus efectos en los diversos organos nerviosos de vertebrados e invertebrados. Trab Lab Invest Biol Univ Madrid 2: 129-221.

Cajal SRy. 1910. El núcleo de las células piramidales del cerebro humano y del algunos mamiferos. Trab Lab Invest Biol Univ Madrid 8: 27-62.

Capelson M, Liang Y, Schulte R, Mair W, Wagner U, Hetzer MW. 2010. Chromatin-bound nuclear pore components regulate gene expression in higher eukaryotes. Cell 140: $372-383$.

Chauveau J, Moule Y, Rouiller C. 1956. Isolation of pure and unaltered liver nuclei: morphology and biochemical composition. Exp Cell Res 11: 317-321.

Chen D, Huang S. 2001. Nucleolar components involved in ribosome biogenesis cycle between the nucleolus and nucleoplasm in interphase cells. J Cell Biol 153: 169-176.

Chuang CH, Carpenter AE, Fuchsova B, Johnson T, de Lanerolle P, Belmont AS. 2006. Long-range directional movement of an interphase chromosome site. Curr Biol 16: $825-831$.

Chubb JR, Bickmore WA. 2003. Considering nuclear compartmentalization in the light of nuclear dynamics. Cell 112: $403-406$.

Clemson CM, Hutchinson JN, Sara SA, Ensminger AW, Fox AH, Chess A, Lawrence JB. 2009. An architectural role for a nuclear noncoding RNA: NETA1 RNA is essential for the structure of paraspeckles. Mol Cell 33: 717-726.

Cocco L, Faenza I, Follo MY, Billi AM, Ramazzotti G, Papa V, Martelli AM, Manzoli L. 2009. Nuclear inositides: Pl-PLC signaling in cell growth, differentiation and pathology. Adv Enzyme Reg 49: 2-10.

Couté Y, Burgess JA, Diaz JJ, Chichester C, Lisacek F, Greco A, Sanchez JC. 2006. Deciphering the human nucleolar proteome. Mass Spect Rev 25: 215-234.

Cremer T, Cremer C. 2001. Chromosome territories, nuclear architecture and gene regulation in mammalian cells. Nat Rev Genet 2: 292-301.

Cremer T, Cremer C. 2006. Rise, fall and resurrection of chromosome territories: a historical perspective. Part II: Fall and resurrection of chromosome territories during the 1950s and 1960s. Part III: Chromosome territories and the functional nuclear architecture: experiments and models from the 1990s to the present. Eur J Histochem 50: 223-272.

Cremer T, Cremer M, Dietzel S, Muller S, Solovei I, Fakan S. 2006. Chromosome territories-a functional nuclear landscape. Curr Opin Cell Biol 18: 307-316.

Cremer T, Cremer C, Schenider T, Baumann H, Hens L, Kirsch-Volders M. 1982. Analysis of chromosome positions in the interphase nucleus of Chinese hamster cells 


\section{T. Pederson}

by laser-UV-microirradiation experiments. Hum Genet 62: 201-209.

Dahlberg JE, Lund E, Goodwin EB. 2003. Nuclear translation: what is the evidence? RNA 9: $1-8$.

Dange T, Grünwald D, Grünwald A, Peters R, Kubitscheck U. 2008. Autonomy and robustness of translocation through the nuclear pore complex: a single-molecule study. J Cell Biol 183: 77-86.

Dechat T, Pfleghaar K, Sengupta K, Shimi T, Shumaker DK, Solimando L, Goldman RD. 2008. Nuclear lamins: major factors in the structural organization and function of the nucleus and chromatin. Genes Dev 22: 832-853.

Dekker J, Rippe K, Dekker M, Kleckner N. 2002. Capturing chromosome conformation. Science 295: 1306-1311.

Deniaud E, Bickmore WA. 2009. Transcription and the nuclear periphery: edge of darkness? Curr Opin Genet Dev 19: 187-191.

Divecha N, Banfić F, Irvine RF. 1993. Inositides and the nucleus and inositides in the nucleus. Cell 74: 405-407.

Dostie J, Dekker J. 2007. Mapping networks of physical interactions between genomic elements using $5 \mathrm{C}$ technology. Nat Protocols 2: 988-1002.

Dundr M, McNally JG, Cohen J, Misteli T. 2002. Quantitation of GFP-fusion proteins in single living cells. J Struct Biol 140: 92-99.

Dundr M, Misteli T. 2002. Nucleolomics: an inventory of the nucleolus. Mol Cell 9: 5-7.

Dundr M, Ospina JK, Sung MH, John S, Upender M, Ried T, Hager GL, Matera AG. 2007. Actin-dependent intranuclear repositioning of an active gene locus in vivo. J Cell Biol 179: 1095-1103.

DuPraw EJ. 1970. DNA and Chromosomes Holt, Rinehart \& Winston, New York.

Duryee WR. 1954. Microdissection studies on human ovarian eggs. Trans NY Acad Sci 17: 103-108.

Eils R, Gerlich D, Tvaruskó W, Spector DL, Misteli T. 2000. Quantitative imaging of pre-mRNA splicing factors in living cells. Mol Biol Cell 11: 413-418.

Fawcett DW. 1966. On the occurrence of a fibrous lamina on the inner aspect of the nuclear envelope in certain cells of vertebrates. Am J Anat 119: 129-145.

Fernandez-Martinez J, Rout MP. 2009. Nuclear pore complex biogenesis. Curr Opin Cell Biol 21: 603-612.

Foster HA, Bridger JM. 2005. The genome and the nucleus: a marriage made by evolution. Chromosoma 114: 212-229.

Gall JG. 1964. Electron microscopy of the nuclear envelope. Protoplasmatologia 5: 4-25.

Gall JG. 1967. Octagonal nuclear pores. J Cell Biol 32: 391399.

Gall JG. 1974. Free ribosomal RNA genes in the macronucleus of Tetrahymena. Proc Natl Acad Sci USA 71: 3078-3081.

Gall JG. 1996. A pictorial history. Views of the cell. American Society for Cell Biology, Bethesda, MD.

Gall JG. 2000. Cajal bodies: the first 100 years. Ann Rev Cell Dev Biol 16: 273-300.

Gall JG. 2009. Chromosome odds and ends. Ann Rev Cell Dev Biol, in press.
Gall JG, Pardue ML. 1969. Formation and detection of RNA-DNA hybrid molecules in cytological preparations. Proc Natl Acad Sci 63: 378-383.

Gasser SM. 2002. Visualizing chromatin dynamics in interphase nuclei. Science 296: 1412-1416.

Gilbert N, Gilchrist S, Bickmore WA. 2005. Chromatin organization in the mammalian nucleus. Int Rev Cytol 242: $283-336$.

Goldstein L. 1970. On the question of protein synthesis by cell nuclei. Adv Cell Biol 1: 187-210.

Gorski S, Misteli T. 2005. Systems biology in the cell nucleus. J Cell Sci 118: 4083-4092.

Grünwald D, Martin RM, Buschmann V, Bazett-Jones DP, Leonhardt H, Kubitscheck U, Cardoso MC. 2008. Probing intranuclear environments at the single-molecule level of detection. Biophys J 94: 2847-2858.

Gurney T, Eliceiri GL. 1980. Intracellular distribution of low molecular weight RNA species in HeLa cells. J Cell Biol 87: 398-403.

Handwerger KE, Cordero JA, Gall JG. 2005. Cajal bodies, nucleoli, and speckles in the Xenopus oocyte nucleus have a low-density, sponge-like structure. Mol Biol Cell 16: $202-211$.

Handwerger KE, Gall JG. 2006. Subnuclear organelles: new insights into form and function. Trends Cell Biol 16: $19-26$.

Harris H. 1999. The birth of the cell. Yale University Press, New Haven.

Hinsby AM, Kiemer L, Karlberg EO, Lage K, Fausbøll A, Juncker AS, Andersen JS, Mann M, Brunak S. 2006. A wiring of the human nucleolus. Mol Cell 22: 285-295.

Holland CA, Mayrand SH, Pederson T. 1980. Sequence complexity of nuclear and messenger RNA in HeLa cells. J Mol Biol 138: 755-778.

Hoppe-Seyler F. 1871. Über die chemische zusammensetzung des eiters. Hoppe-Seyler's Medizinisch-Chemischen Untersuchungen 4: 486-501.

Houtsmuller AB, Rademakers S, Nigg AL, Hoogstraten D, Hoeijmakers JHJ, Vermuelen W. 1999. Action of DNA repair endonuclease ERCC1/XPF in living cells. Science 284: 958-961.

Hu Q, Kwon YS, Nunez E, Cardamone MD, Hutt KR, Ohgi KA, Garcia-Bassets I, Rose DW, Glass CK, Rosenfeld MG, et al. 2008. Enhancing nuclear receptor-induced transcription requires nuclear motor and LSD1-dependent gene networking in interchromatin granules. Proc Natl Acad Sci USA 105: 19199-19204.

Huang S, Derrinck TJ, Ellisman MH, Spector DL. 1997. The dynamic organization of the perinucleolar compartment in the cell nucleus. J Cell Biol 137: 965-974.

Huang S, Derrinck TJ, Ellisman MH, Spector DL. 1998. The perinucleolar compartment and transcription. J Cell Biol 143: 35-47.

Iborra FJ, Jackson DA, Cook PR. 2001. Coupled transcription and translation within nuclei of mammalian cells. Science 293: 1139-1142.

Jacobson MR, Cao LC, Wang YL, Pederson T. 1995. Dynamic localization of RNase MRP RNA in the nucleolus observed by fluorescent RNA cytochemistry in living cells. J Cell Biol 131: 1649-1658. 
Jacobson MR, Pederson T. 1998. A 7-methylguanosine cap commits U3 and U8 small nuclear RNAs to the nucleolar localization pathway. Nucleic Acids Res 26: 756-760.

Janicki SM, Tsukamoto T, Salghetti SE, Tansey WP, Sachidanandam R, Prasanth KV, Ried T, Shav-Tal Y, Bertrand E, Singer RH, et al. 2004. From silencing to gene expression: real-time analysis in single cells. Cell 116: 683-698.

Kaiser TE, Intine RV, Dundr M. 2008. De novo formation of a subnuclear body. Science 322: 1713-1717.

Kalverda B, Pickersgill H, Shloma VV, Fornerod M. 2010 Nucleoporins directly stimulate expression of developmental and cell-cycle genes inside the nucleoplasm. Cell 140: $360-371$.

Kamath RV, Thor AD, Wang C, Edgerton SM, Slusarczyk A Leary DJ, Wang J, Wiley EL, Jovanovic B, Wu Q, et al. 2005. Perinucleolar compartment prevalence has an independent prognostic value for breast cancer. Cancer Res 65: 246-253.

Karpova TS, Kim MJ, Spriel C, Nalley K, Stasevich TJ, Kherrouche Z, Heliot L, McNally JG. 2008. Concurrent fast and slow cycling of a transcriptional activator at an endogenous promoter. Science 319: 466-469.

King MC, Drivas TG, Blobel G. 2008. A network of nuclear envelope membrane proteins linking centromeres to microtubules. Cell 134: 427-438.

Kleinschmidt AM, Pederson T. 1990. RNA processing and ribonucleoprotein assembly studied in vivo by RNA transfection. Proc Natl Acad Sci 87: 1283-1287.

Kruhlak MJ, Lever MA, Fischle W, Verdin E, Bazaett-Jones DP, Hendzel MJ. 2000. Reduced mobility of the alternate splicing factor (ASF) through the nucleoplasm and steady state speckle compartments. J Cell Biol 150: 41-51.

Lake JA. 2009. Evidence of an early prokaryotic endosymbiosis. Nature 460: 967-971.

Lam YW, Lyon CE, Lamond AI. 2002. Large-scale isolation of Cajal bodies from HeLa cells. Mol Biol Cell 13: 2461-2473.

Lamond AI, Spector DL. 2003. Nuclear speckles: a model for nuclear organelles. Nat Rev Mol Cell Biol 4: 605-612.

Lander AD. 2009. The 'stem cell' concept: is it holding us back? J Biol 8: 70.

Langowski J. 2010. Chromosome conformation by crosslinking: polymer physics matters. Nucleus 1: 13-16.

Lee DC, Welton KL, Smith ED, Kennedy BK. 2009. A-type nuclear lamins act as transcriptional repressors when targeted to promoters. Exp Cell Res 315: 996-1007.

Lever MA, Th'ng JP, Sun X, Hendzel MJ. 2000. Rapid exchange of histone H1.1 on chromatin in living cells. Nature 408: 873-876.

Leung AK, Trinkle-Mullcahy L, Lam YW, Andersen JS, Mann M, Lamond AI. 2006. NOPdb: nucleolar proteome database. Nucleic Acid Res 34: D218-220.

Lieberman-Aiden E, van Berkum NL, Williams L, Imakaev M, Ragoczy T, Telling A, Amit I, Lajoie BR, Sabo PJ, Dorschner MO, et al. 2009. Comprehensive mapping of long-range interactions reveals folding principles of the human genome. Science 326: 289-293.

Lund E, Paine P. 1990. Nonaqueous isolation of transcriptionally active nuclei from Xenopus oocytes. Methods Enzymol 181: 36-43.
Maggio R, Siekevitz P, Palade GE. 1963. Studies on isolated nuclei. I. Isolation and chemical characterization of a nuclear fraction from guinea pig liver. J Cell Biol 18: 267-291.

Maggio R, Siekevitz P, Palade GE. 1963. Studies on isolated nuclei. II. Isolation and chemical characterization of nucleolar and nucleoplasmic subfractions. J Cell Biol 18: $292-312$.

Malhas A, Lee CF, Sanders R, Saunders NJ, Vaux DJ. 2007. Defects in lamin $\mathrm{B} 1$ expression or processing affect interphase chromosome position and gene expression. J Cell Biol 176: 593-603.

Margulis L, Dolan MF, Guerrero R. 2000. The chimeric eukaryote: origin of the nucleus from the karyomastigont in amitochondriate protists. Proc Natl Acad Sci 97: 6954-6959.

Marshall WF, Straight A, Marko JF, Swedlow J, Dernburg A, Belmont A, Murray AW, Agard DA, Sedat JW. 1997. Interphase chromosomes undergo constrained diffusional motion in living cells. Curr Biol 7: 930-939.

Martelli AM, Gilmour RS, Bertagnolo V, Neri LM, Manzoli L, Cocco L. 1991. Nuclear localization and signalling activity of phosphoinositidase $\mathrm{C}_{\beta}$ in Swiss 3T3 cells. Nature 358: 242-244.

Matera AG, Frey MR, Margelot K, Wolin SL. 1995. A perinucleolar compartment contains several RNA polymerase III transcripts as well as the polypyrimidine tract binding protein, hnRNP I. J Cell Biol 129: 1181-1193.

Meaburn KJ, Newbold RF, Bridger JM. 2008. Positioning of human chromosomes in murine cell hybrids according to synteny. Chromosoma 117: 579-591.

Meaburn KJ, Gugla PR, Khan S, Lockett SJ, Misteli T. 2009. Disease-specific gene repositioning in breast cancer. $J$ Cell Biol 187: 801-812.

Mehlin H, Daneholt B, Skoglund U. 1992. Translocation of a specific premessenger ribonucleoprotein particle through the nuclear pore studied with electron microscope tomography. Cell 15: 605-613.

Miescher F. 1871. Über die chemische zusammensetzung der eiterzellen. Hoppe-Seyler's Medizinisch-Chemischen Untersuchungen 4: 441-460.

Mintz PJ, Patterson SD, Neuwald AF, Spahr CS, Spector DL. 1999. Purification and biochemical characterization of interchromatin granule clusters. EMBO J 18: 4308-4320.

Misteli T, Gunjan A, Hock R, Bustin M, Brown DT. 2000. Dynamic binding of histone $\mathrm{H} 1$ to chromatin in living cells. Nature 408: 877-881.

Misteli T. 2001a. Where the nucleus comes from. Trends Cell Biol 11: 149.

Misteli T. 2001b. Protein dynamics: implications for nuclear architecture and gene expression. Science 291: 843-847.

Misteli T. 2001c. The concept of self-organization in cellular architecture. J Cell Biol 155: 181-185.

Misteli T. 2007. Beyond the sequence: cellular organization of genome function. Cell 128: 787-800.

Misteli T. 2009. Self-organization in the genome. Proc Natl Acad Sci USA 106: 6885-6886.

Misteli T, Cáceres JF, Spector DL. 1997. The dynamics of a pre-mRNA splicing factor in living cells. Nature 387: 523-527. 


\section{T. Pederson}

Moir RD, Yoon M, Khuon S, Goldman RD. 2000. Nuclear lamins A and B1: different pathways of assembly during nuclear envelope formation in living cells. J Cell Biol 151: $1155-1168$.

Muramatsu M, Smetana K, Busch H. 1963. Quantitative aspects of isolation of nucleoli of the Walker carcinosarcoma and liver of the rat. Cancer Res 23: 510-518.

Muratani M, Gerlich D, Janicki SM, Gebhard M, Eils R, Spector DL. 2002. Metabolic-energy-dependent movement of PML bodies within the mammalian cell nucleus. Nature Cell Biol 4: 106-110.

Nathanson L, Xia T, Deutscher MP. 2003. Nuclear protein synthesis: a re-evaluation. RNA 9: 9-13.

Newport JW, Forbes DJ. 1987. The nucleus: structure, function, and dynamics. Ann Rev Biochem 56: 535-565.

Nizami Z, Deryusheva S, Gall J. 2010. The Cajal body and histone locus body. Cold Spring Harb Perspect Biol 2: a000653.

O’Brien TP, Bult CJ, Cremer C, Grunze M, Knowles BB, Langowski J, McNally J, Pederson T, Politz JC, Pombo A, et al. 2003. Genome function and nuclear architecture: from gene expression to nanoscience. Genome Res 13: 1029-1041.

Olins AL, Olins DE. 1974. Spheroid chromatin units ( $v$ bodies). Science 183: 330-332.

Paine PL, Johnson ME, Lau YT, Tluczek LJM, Miller DS. 1992. The oocyte nucleus isolated in oil retains in vivo structure and functions. Biotechniques 13: 238-245.

Parnell EJ, Stillman DJ. 2008. Getting a transcription factor to only one nucleus following mitosis. PLoS Biol 6: $1829-1832$.

Pearse AGE. 1961. Histochemistry. 2nd edition, Little, Brown and Co., Boston.

Pederson T. 1976. Cellular aspects of histone synthesis. In Protein synthesis (ed. E.H. McConkey), Vol. 2: pp. 69-123, Marcel Dekker, New York.

Pederson T. 1998. Thinking about a nuclear matrix. J Mol Biol 277: 147-159.

Pederson T. 2000a. Half a century of "the nuclear matrix". Mol Biol Cell 11: 799-805.

Pederson T. 2000b. Diffusional protein transport within the nucleus: a message in the medium. Nature Cell Biol 2: E73-74.

Pederson T. 2001a. Is the nucleus in need of translation? Trends Cell Biol 11: 395-397.

Pederson T. 2001b. Protein mobility within the nucleuswhat are the right moves? Cell 104: 635-638.

Pederson T. 2001c. Fluorescent RNA cytochemistry: tracking gene transcripts in living cells. Nucleic Acids Res 29: 1013-1016.

Pederson T. 2002a. Dynamics and genome-centricity of inter-chromatin domains in the nucleus. Nat Cell Biol 4: E287-E291.

Pederson T. 2002b. Proteomics of the nucleolus: more proteins, more functions? Trends Biochem. Sci 27: 111-112.

Pederson T. 2003. Gene territories and cancer. Nature Genetics 34: $242-243$.

Pederson T. 2004. The spatial organization of the genome in mammalian cells. Curr Opin Genet Dev 14: 203-209.
Pederson T. 2005. In memoriam- Hans Ris. Chromosoma 114: 307-309.

Pederson T. 2006. Diffraction at the Brandeburg g(r)ate. EMBO reports 7: 1202-1205.

Pederson T. 2008. As functional nuclear actin comes into view, is it globular, filamentous, or both? J Cell Biol 180: $1061-1064$.

Pederson T. 2010. An olympian protozoan. Nucleus 1: 1-3.

Pederson T, Aebi U. 2002. Actin in the nucleus: what form and what for? J Struct Biol 140: 3-9.

Pederson T, Aebi U. 2005. Nuclear actin extends, with no contraction in sight. Mol Biol Cell 16: 5055-5060.

Pendle AF, Clark GP, Boon R, Lewandowska D, Lam YW, Andersen J, Mann M, Lamond AI, Brown JW, Shaw PJ. 2005. Proteomic analysis of the Arabidopsis nucleolus suggest novel nucleolar functions. Mol Biol Cell 16: 260-269.

Penman S. 1966. RNA metabolism in the Hela cell nucleus. J Mol Biol 17: 117-130.

Phair RD, Misteli T. 2000. High mobility of proteins in the mammalian cell nucleus. Nature 404: 604-609.

Phair RD, Misteli T. 2001. Kinetic modeling approaches to in vivo imaging. Nat Rev Mol Cell Biol 2: 898-907.

Platani M, Goldberg I, Lamond AI, Swedlow JR. 2002. Cajal body dynamics and association with chromatin are ATP-dependent. Nat Cell. Biol 4: 502-508.

Politz JCR, Pederson T. 2000. Review: movement of mRNA from transcription site to nuclear pores. J Struc Biol 129: 252-257.

Politz JC, Lewandowski LB, Pederson T. 2002. Signal recognition particle RNA localization within the nucleolus differs from the classical sites of ribosome synthesis. J Cell Biol 159: 411-418.

Politz JCR, Tuft RA, Pederson T. 2003. Diffusion-based transport of nascent ribosomes in the nucleus. Mol Biol Cell 14: 4805-4812.

Politz JC, Brown ES, Wolf DE, Pederson T. 1998. Intranuclear diffusion and hybridization state of oligonucleotides measured by fluorescence correlation spectroscopy in living cells. Proc Natl Acad Sci 95: 6043-6048.

Politz JCR, Polena I, Trask I, Bazett-Jones DP, Pederson T. 2005. A nonribosomal landscape in the nucleolus revealed by the stem cell protein nucleostemin. Mol Biol Cell 16: $3401-4310$.

Politz JC, Tuft RA, Pederson T, Singer RH. 1999. Movement of nuclear poly(A) RNA throughout the interchromatin space in living cells. Curr Biol 9: 285-291.

Politz JCR, Tuft RA, Prasanth KV, Baudendistel N, Fograt KE, Lifshitz LM, Langowski J, Spector DL, Pederson T. 2006. Rapid, diffusional shuttling of poly(A) RNA between nuclear speckles and the nucleoplasm. Mo Biol Cell 17: 1239-1249.

Poole A, Penny D. 2001. Does endo-symbiosis explain the origin of the nucleus? Nat Cell Biol 3: E173-E174.

Portugal FH, Cohen JS. 1977. ACentury of DNA. MIT Press, Cambridge, MA.

Purkyně JE. 1825. Symbolae ad ovi avium historiam ante incubationem. 1st ed. Vratislaviae. Reprinted 1948: Opera selecta. Tomus 1, Opera facultatis medicae universitatis carolinae pragensis.

Rabl C. 1885. Über zelltheilung. Morph Jb 10: 214-330. 
Ragoczy T, Groudine M. 2009. The nucleus inside outthrough a rod darkly. Cell 137: 205-207.

Rajapakse I, Perlman MD, Scalzo D, Kooperberg C, Groudine M, Kosak ST. 2009. The emergence of lineage-specific chromosomal topologies from coordinate gene regulation. Proc Natl Acad Sci USA 106: 6679-6684.

Raška I, Andrade LEC, Ochs RL, Chan EKL, Chang CM, Roos G, Tan EM. 1991. Immunological and ultrastructural studies of the nuclear coiled body with autoimmune antibodies. Exp Cell Res 195: 27-37.

Reddy R, Busch H. 1988. Small nuclear RNAs: sequences, structure and modifications. In Structure and function of major and minor small nuclear ribonucleoprotein particles M.L. Birnstiel, ed. Springer-Verlag, Berlin, pp. 1-37.

Robinett CC, Straight A, Li G, Willhelm C, Sudlow G, Murray A, Belmont AS. 1996. In vivo localization of DNA sequences and visualization of large-scale chromatin organization using lac operator/repressor recognition. J Cell Biol 135: 1685-1700.

Robbins E, Pederson T. 1970. Iron: its intracellular localization and possible role in cell division. Proc Natl Acad Sci USA 66: 1244-1251.

Robbins E, Pederson T, Klein P. 1970. Comparison of mitotic phenomena and effects induced by hypertonic solutions in HeLa cells. J Cell Biol 44: 400-416.

Roix JJ, McQueen PG, Munson PJ, Parada LA, Misteli T. 2003. Spatial proximity of translocation-prone gene loci in lymphomas. Nat Genetics 34: 287-291.

Rotte C, Martin W. 2001. Does endo-symbiosis explain the origin of the nucleus? Nat Cell Biol 3: E173-E174.

Roux KJ, Crisp ML, Liu Q, Kim D, Kozlov S, Stewart CL, Burke B. 2009. Nesprin 4 is an outer nuclear membrane protein that can induce kinesin-mediated cell polarization. Proc Natl Acad USA 106: 2194-2199.

Saitoh N, Spahr CS, Patterson SD, Bubulya P, Neuwald AF, Spector DL. 2004. Proteomic analysis of interchromatin granule clusters. Mol Biol Cell 15: 3876-3890.

Sasaki YTF, Ideue T, Sano M, Mituyama T, Hirose T. 2009. MEN e/b noncoding RNAs are essential for structural integrity of nuclear paraspeckles. Proc Natl Acad Sci USA 106: $2525-2530$.

Scherl A, Couté Y, Deon C, Calle K, Kindbeiter K, Sanchez JD, Greco A, Hochstrasser D, Diaz JJ. 2002. Functional proteomic analysis of human nucleolus. Mol Biol Cell 13: $4100-4109$.

Sexton T, Schober H, Fraser P, Gasser SM. 2007. Gene regulation through nuclear organization. Nat Struc. Mol Biol 14: 1049-1055.

Shav-Tal Y, Darzacq X, Shenoy SM, Fusco D, Janicki SM, Spector DL, Singer RH. 2004. Dynamics of single mRNPs in nuclei of living cells. Science 304: 1797-1800.

Shimi T, Pfleghaar K, Kojima S, Pack CG, Solovei I, Goldman AE, Adam SA, Shumaker DK, Kinjo M, Cremer T, et al. 2008. The A- and B-type nuclear lamin networks: microdomains involved in chromatin organization and transcription. Genes Dev 22: 3409-3421.

Shumaker DK, Solimando L, Sengupta K, Shimi T, Adam SA, Grunwald A, Strelkov SV, Aebi U, Cardoso MC, Goldman RD. 2008. The highly conserved nuclear lamin
Ig-fold binds to PCNA: its role in DNA replication. J Cell Biol 181: 269-280.

Siebrasse JP, Veith R, Dobay A, Leonhardt H, Daneholt B, Kubitscheck U. 2009. Discontinuous movement of mRNP particles in nucleoplasmic regions devoid of chromatin. Proc Natl Acad Sci 105: 20291-20296.

Singh OP, Björkroth B, Masich S, Wieslander L, Daneholt B. 1999. The intranuclear movement of Balbiani ring premessenger ribonucleoprotein particles. Exp Cell Res 251: 135-146.

Solovei I, Kreysing M, Lanctôt C, Kösem S, Peichl L, Cremer T, Guck J, Joffe B. 2009. Nuclear architecture of rod photoreceptor cells adapts to vision in mammalian evolution. Cell 137: 356-368.

Spector DL. 1993. Macromolecular domains within the cell nucleus. Ann Rev Cell Biol 9: 265-315.

Spector DL. 2001. Nuclear domains. J Cell Sci 114: 28912893.

Spector DL. 2003. The dynamics of chromosome organization and gene regulation. Ann Rev Biochem 72: 573-608.

Spector DL. 2006. SnapShot: cellular bodies. Cell 127: 1070.

Sprouse RO, Karpova TS, Mueller F, Dasgupta A, McNally JG, Auble DT. 2008. Regulation of TATA-binding protein dynamics in living yeast cells. Proc Natl Acad Sci USA 105: 13304-13308.

Sprout D, Gilbert N, Bickmore WA. 2005. The role of chromatin structure in regulating the expression of clustered genes. Nat Rev Genet 6: 775-781.

Starr DA. 2009. A nuclear-envelope bridge positions nuclei and moves chromosomes. J Cell Sci 122: 577-586.

Sunwoo H, Dinger ME, Wilusz JE, Amaral PP, Mattick JS, Spector DL. 2009. MEN e/b nuclear-retained noncoding RNAs are up-regulated upon muscle differentiation and are essential components of paraspeckles. Genome Res 19: 347-359.

Takizawa T, Meaburn KJ, Misteli T. 2008. The meaning of gene positioning. Cell 135: 9-13.

Tanabe H, Muller S, Neusser M, von Hase J, Calcagno E, Cremer M, Solovei I, Cremer C, Cremer T. 2002. Evolutionary conservation of chromosome territory arrangements in cell nuclei from higher primates. Proc Natl Acad Sci USA 99: 4424-4429.

Towbin BD, Meister P, Gasser SM. 2009. The nuclear envelope- a scaffold for silencing? Curr Opin Genet Dev 19: $180-186$.

Traub A, Kaufmann E, Ginzburg-Tietz Y. 1964. Studies on nuclear ribosomes. I. Association of DPN-pyrophosphorylase with nuclear ribosomes in normal and neoplastic tissues. Exp Cell Res 34: 371-383.

Tsukamoto T, Hashiguchi N, Janicki SM, Tumbar T, Belmont AS, Spector DL. 2000. Visualization of gene activity in living cells. Nat Cell Biol 2: 871-878.

Vincent WS. 1955. Structure and chemistry of nucleoli. Int Rev Cytol 4: 269-298.

Wachsmuth M, Waldeck W, Langowski J. 2000. Anomalous diffusion of fluorescent probes inside living cell nuclei investigated by spatially-resolved fluorescence correlation spectroscopy. J Mol Biol 298: 677-689. 


\section{T. Pederson}

Wang J, Cao LG, Wang YL, Pederson T. 1990. Localization of pre-messenger RNA at discrete nuclear sites. Proc Natl Acad Sci 88: 7391-7395.

Weber J, Jelinek W, Darnell JE. 1977. The definition of large viral transcription unit late in Ad2 infection of HeLa cells: mapping of nascent RNA molecules labeled in isolated nuclei. Cell 10: 611-616.

Weng C, Politz JC, Pederson T, Huang S. 2003. RNA polymerase III transcripts and the PTB protein are essential for the integrity of the perinucleolar compartment. $\mathrm{Mol}$ Biol Cell 14: 2425-2435.

Wilson EB. 1925. The cell in development and heredity. 3rd edition. Macmillan, New York, NY, pp. 28-57.
Wilusz JE, Sunwoo H, Spector DL. 2009. Long noncoding RNAs: functional surprises from the RNA world. Genes Dev 23: 1494-1504.

Zbarsky IB, Georgiev GP. 1959. Cytological characteristics of protein and nucleoprotein fractions of cell nuclei. Biochim Biophys Acta 32: 301-302.

Zieve GW, Sauterer RA, Feeney RJ. 1988. Newly synthesized small nuclear RNAs appear transiently in the cytoplasm. J Mol Biol 199: 259-267.

Zorn C, Cremer C, Cremer T, Zimmer J. 1979. Unscheduled DNA synthesis after partial UV irradiation of the cell nucleus: distribution in interphase and metaphase. Exp Cell Res 124: 111-119. 


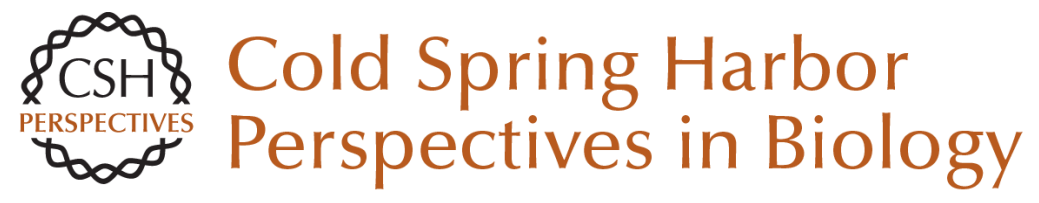

\section{The Nucleus Introduced}

Thoru Pederson

Cold Spring Harb Perspect Biol 2011; doi: 10.1101/cshperspect.a000521 originally published online July 21, 2010

\section{Subject Collection The Nucleus}

Nuclear Compartments: An Incomplete Primer to Nuclear Compartments, Bodies, and Genome Organization Relative to Nuclear Architecture Andrew S. Belmont

Uncovering the Principles of Genome Folding by 3D Chromatin Modeling

Asli Yildirim, Lorenzo Boninsegna, Yuxiang Zhan, et al.

3D or Not 3D: Shaping the Genome during Development Juliane Glaser and Stefan Mundlos

The Impact of Space and Time on the Functional Output of the Genome Marcelo Nollmann, Isma Bennabi, Markus Götz, et al.

\section{Chromatin Mechanisms Driving Cancer}

Berkley Gryder, Peter C. Scacheri, Thomas Ried, et al.

\section{Liquid-Liquid Phase Separation in Chromatin Karsten Rippe}

Mechanical Forces in Nuclear Organization Yekaterina A. Miroshnikova and Sara A. Wickström

Imaging Organization of RNA Processing within the Nucleus

Jeetayu Biswas, Weihan Li, Robert H. Singer, et al.
Mechanisms of Chromosome Folding and Nuclear Organization: Their Interplay and Open Questions Leonid Mirny and Job Dekker

Epigenetic Reprogramming in Early Animal Development

Zhenhai Du, Ke Zhang and Wei Xie

Essential Roles for RNA in Shaping Nuclear Organization

Sofia A. Quinodoz and Mitchell Guttman

The Molecular and Nuclear Dynamics of

$\mathrm{X}$-Chromosome Inactivation

François Dossin and Edith Heard

Structure, Maintenance, and Regulation of

Nuclear Pore Complexes: The Gatekeepers of the

Eukaryotic Genome Marcela Raices and Maximiliano A. D'Angelo

The Nuclear Lamina Xianrong Wong, Ashley J. Melendez-Perez and Karen L. Reddy

The Nuclear Pore Complex as a Transcription Regulator Michael Chas Sumner and Jason Brickner

Physical Nature of Chromatin in the Nucleus Kazuhiro Maeshima, Shiori lida and Sachiko Tamura

For additional articles in this collection, see http://cshperspectives.cshlp.org/cgi/collection/

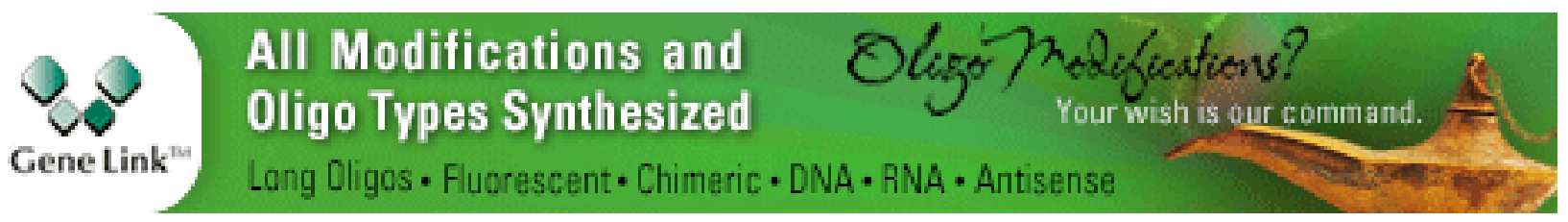


For additional articles in this collection, see http://cshperspectives.cshlp.org/cgi/collection/

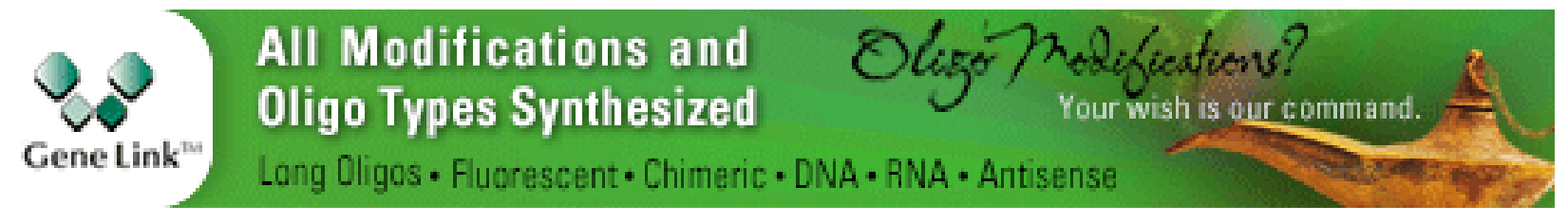

Copyright @ 2011 Cold Spring Harbor Laboratory Press; all rights reserved 